\title{
Påvisning av nitrometan i blod
}

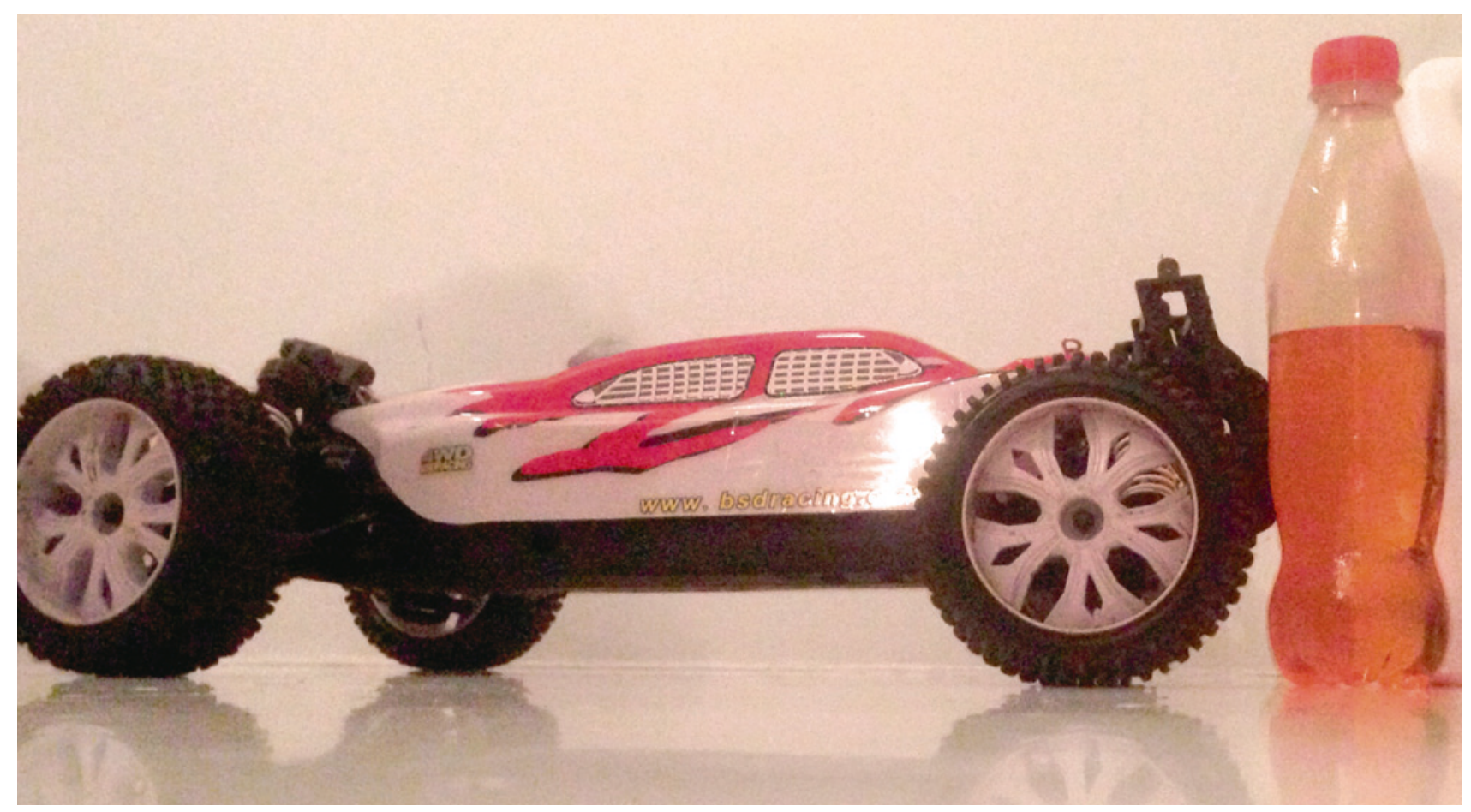

En gutt i barnehagealder ble henvist til akuttmottak 20 timer etter at han ved et uhell hadde drukket ca. $10 \mathrm{ml}$ av drivstoffet til en radiostyrt bil (bildet). Drivstoffet inneholdt $80 \%$ metanol og $20 \%$ nitrometan. Kort tid etter inntaket kastet han opp to ganger. Han ble innlagt til observasjon i god allmenntilstand, med normale vitale tegn og normal organstatus. Blodprøver viste normale elektrolytter og normal syre-base-status og osmolalt gap, men lett forhøyet aniongap ( $22 \mathrm{mmol} / \mathrm{l})$.

Gutten ble utskrevet åtte timer senere, etter at verken metanol eller maursyre ble påvist. Under leting etter metanol i prøven fant laboratoriet nitrometan $i$ serum ved hjelp av rutinemessig massescreening på dampfasegasskromatografimassespektrometri (headspace GC-MS) med biblioteksøk. Nivået ble senere kvantifisert til $47 \mathrm{mg} / 1(0,77 \mathrm{mmol} / \mathrm{l})$. Nitrometannivået var klart høyere enn det som er rapportert hos personer uten kjent eksponering (1).

Det er så vidt vi vet ikke tidligere publisert analysemetoder for å påvise eller kvantifisere nitrometan. Headspace GC-MS med massescreening og biblioteksøk er en fleksibel metode som kan identifisere et stort antall gassformige eller flyktige substanser, for eksempel lightergasser, løsemidler, anestesigasser eller denatureringsmidler for sprit. Prøver kan sendes til Seksjon for klinisk farmako- logi, Oslo universitetssykehus, Ullevål. Gasser og lettflyktige substanser bør sendes nedkjølt $\mathrm{i}$ tett emballasje. Før innsending av prøve bør rekvirenter konferere med laboratoriet.

Pasientens pårørende har gitt tillatelse til at artikkelen blir publisert.

\section{Ingvild S. Ask}

insask@ous-hf.no

Barne- og ungdomsklinikken

Oslo universitetssykehus, Ullevål

\section{Siri Føreid}

Seksjon for klinisk farmakologi Oslo universitetssykehus, Ullevål

\section{Charlotte K. Knatten}

Barne- og ungdomsklinikken

Oslo universitetssykehus, Ullevål

\section{Sean C. Wallace}

Barne- og ungdomsklinikken

Oslo universitetssykehus, Ullevål

\section{Gaut Gadeholt}

Seksjon for klinisk farmakologi

Oslo universitetssykehus, Ullevål

Ingvild S. Ask (f. 1981) er lege i spesialisering i barnesykdommer.

Forfatter har fylt ut ICMJE-skjemaet og oppgir ingen interessekonflikter.
Siri Føreid (f. 1964) er m.sc. og overingeniør. Forfatter har fylt ut ICMJE-skjemaet og oppgir ingen interessekonflikter.

Charlotte K. Knatten (f. 1983) er ph.d. og lege i spesialisering i barnesykdommer.

Forfatter har fylt ut ICMJE-skjemaet og oppgir ingen interessekonflikter.

Sean C. Wallace (f.1976) er ph.d. og spesialist i barnesykdommer.

Forfatter har fylt ut ICMJE-skjemaet og oppgir ingen interessekonflikter.

Gaut Gadeholt (f.1951) er dr.med. og overlege. Forfatter har fylt ut ICMJE-skjemaet og oppgir ingen interessekonflikter.

\section{Litteratur \\ 1. Alwis KU, Blount BC, Silva LK et al. Method for quantifying nitromethane in blood as a potential biomarker of halonitromethane exposure. Environ Sci Technol 2008; 42: 2522-7.}

Mottatt 2.2. 2016, første revisjon innsendt 3.5. 2016, godkjent 21.11. 2016. Redaktør: Martine Rostadmo. 